2.

\title{
"Ruinensehnsucht"
}

\section{Longing for Decay in Computer Games}

\author{
Mathias Fuchs
}

Transactions of the Digital Games Research Association

2017, Vol. 3, No. 2, pp. 37-56

ISSN 2328-9422

http://todigra.org

TEXT: Licensed under Creative Commons Attribution (CC BY-

NC- ND 2.5) http://creativecommons.org/licenses/by-nc- nd/2.5/

IMAGES: All images appearing in this work are property of the respective copyright owners, and are not released into the Creative Commons. The respective owners reserve all rights.

\section{ABSTRACT}

There is no technical reason and no quality inherent to the medium of computer games that would require corrosion, dust, and ruins. Pixels do not corrode and 3D geometry is not affected by physical decay. Yet if we look at contemporary computer games we find an abundance of ruined buildings, of mould and of all forms of decay of organic matter and inorganic materials. It would be too easy to explain this fact by an attempt to increase realism, because some of these games clearly feature more decay than reality could ever produce. There must be a longing by designers and players to immerse themselves within an environment of 
disintegrating, decaying objects. The author investigates the longing for decay along four threads that are informed by computer games history, art history, psychoanalytic reasoning and the concept of transmedia megatext.

\section{Keywords}

ruins, digital dust, creative games, computer games history, psychoanalysis, philosophy of games, pathos formula, transmedia megatext.

\section{Digital Dust}

Some of the most interesting of recent computer games celebrate the beauty of ruins and invite us to immerse ourselves in landscapes of ruins from antiquity to the space age. The ruins are set in post-nuclear war environments (Metro 2033) ${ }^{1}$, sites of archaeological excavations and discovery (Tomb Raider) ${ }^{2}$, technological disaster areas (Fallout ${ }^{3}$, S.T.A.L.K.E.R. ${ }^{4}$ ), medieval environments (Assassins's Creed) ${ }^{5}$, industrial wreckage (Unreal Tournament) ${ }^{6}$, mythological places that are known for the buildings they once contained (Ruins) ${ }^{7}$, or even completely fictional places (Journey) ${ }^{8}$.

There is a rich body of research in art history about the meaning and form of ruins, e.g. (Ginsberg, 2002; Böhme, 1989; Dubin, 2010; Wu Hung 2012). In game studies however, only a few papers on the topic have been published (Fraser, 2015; Vella, 2010; Martin, 2001). Ruins are mentioned in Hans Joachim Backe's and Espen Aarseth's text on

1. by Deep Silver (2013)

2. by Eidos (1996)

3. by Interplay Entertainment (1997)

4. by GSC Game World (2008)

5. by Ubisoft (2007)

6. by Epic Games (1999)

7. by Cardboard Computer (2011)

8. by thatgamecompany (2012) 
zombieism (Backe \& Aarseth, 2013: 4) and in Tanya Krzywinska's Zombies in Gamespace that she published in the book with the uncanny title "Autopsies of the living dead in videogames" (Krzywinska, 2008). Both aforementioned texts discuss ruins as some kind of staging for dramatic or ludic content and do not credit ruins as a central object of the game - or even propose that the ruins could at times carry more importance than player characters or rule systems. Emma Fraser's critical approach draws on Walter Benjamin's reflections and tries to attribute the critical power of ruins "to unsettle, even to haunt the dream worlds of contemporary capitalism” (Fraser, 2005). Daniel Vella thoroughly points out spatial features of representations of ruins and connotates those with the player experience.

As far as I know, little has been published about the aspect of "longing for decay" and of the mediatic and game-historic aspects of ruins in ludic 3D environments. One might speak of a longing for decay to describe a phenomenon that consists of a strong affective tie to disintegrating objects. Alluding to German romanticism and in particular to a specific style of painting that has been made popular by Caspar David Friedrich, the appropriate term would be "Ruinensehnsucht". The German word "Sehnsucht" is difficult to translate. "Sehnsucht" is different from "desire” as it is less directed towards gratification, and it is not identical to "longing" as it carries a melancholic connotation that longing need not have. The notion of "Sucht" or addiction is contained within "Sehnsucht". ${ }^{9}$ We can get used to or even be addicted to this particular longing. In the 19th century touristic visits to ancient ruins turned into obsessive admiration of decayed sites in Rome, Palermo or Athens for some, and nowadays urban explorers develop intensive practices to visit decayed spaces in modern cities and industrial wastelands.

If there was a place and time of perfection, where neither rust nor moss, no decay or disasters, and no demolition or ruin were ever seen, 
this would have to be a fictional world - and in our time, probably a computer simulation of a perfect world.

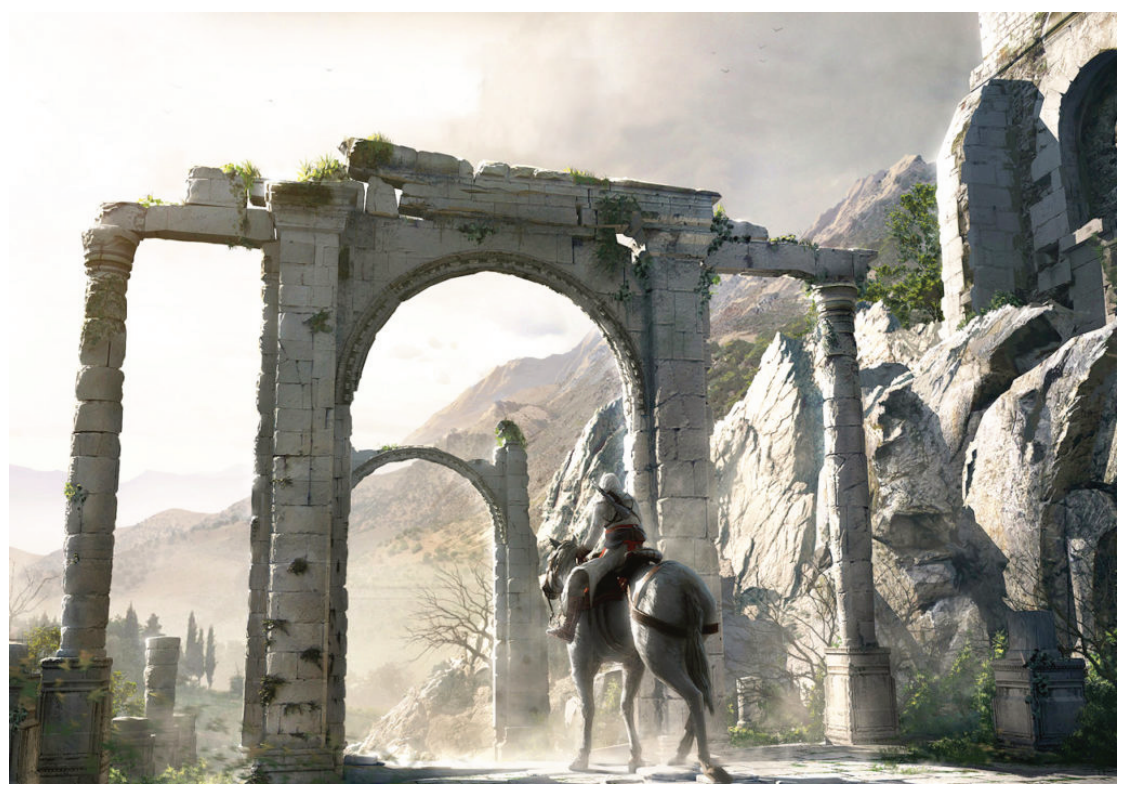

There is no technical or conceptual reason that would make designers of such a world implement decay. There would be no reason for metal to rust, for stone to break and crumble, and for wood to moulder away. Yet if we look at contemporary games we will find abundant ruins, cracks in concrete walls, and corrosion of metal. It would be too easy to explain this by stating that decay just looks realistic in virtual environments, because some of these environments clearly feature more decay than reality could ever produce. There must be a longing of the designers and of the players to immerse themselves within an environment of disintegrating, decaying objects, full of dust, fog, rubble and acid rain.

It is obviously not only the locations and the sites in which these computer games are staged, but also the player's viewpoint, atmospheric lighting, dust and a preference for a certain type of landscape, vegetation, textures, and material that constitute an aesthetic framework for "Ruinensehnsucht", the longing for decay. Such a longing, if expressed in an artistic medium like games, art, architecture or poetry can be 
described as the aesthetic form of a longing for ruins. Hartmut Böhme, a German philosopher and cultural studies researcher uses this notion when he speculates about the dialectics of our fascination with the decline of cities and the decay of historical buildings. In his publication Die Ästhetik der Ruinen (Böhme, 1989) he dates the starting point for an aesthetics of ruins back to the year $1337 .^{10}$ That is when Petrarca, walking on Mont Ventoux with a friend, got involved in the conversation about "tempi passati", times gone. Petrarca described the landscape of ruins that he was looking down upon as a "book of memories" and noted that it is by writing about the ruins that he could counter the permanent decay of those disintegrating buildings. The text, or more generally the artwork provides us with hope for "renevatio", the reconstitution of heroic times. Poetry, from this point in time on, would play with ruins as signifiers for renevatio, but also use them as a theatre of memories and point towards power, eternity, deity and indestructibility. In the 16th century the arts of painting and architecture discovered ruins for their purposes. Ruin painting (Giorgione, e.g.) and the construction of artificial ruins became a means to demonstrate historical knowledge and humanistic education. The first artificial ruin is said to have been erected in 1530 in the Pesaro palace gardens. Hartmut Böhme points out that building a ruin next to a functional building cannot be interpreted as mere contemplation about transience and eternity, but needs to be seen as a statement of power. The ruin next to the functional palace of a sovereign clearly demonstrates power and presence ex negativo. Ruins might signify momentariness, and they can signify the opposite of that: eternity. "This other form to refer ruins to temporal stability consists of building ruins,” says Böhme. “The grottas, artificial ruins or paintings of ruins, that used to be integrated into the dukes' palaces and into the spectacular garden landscapes, lend themselves to a discourse of power - not of melancholia.” (Böhme, 1989: 297)

10. Cynthia Finlayson corrected me in erroneously believing Hartmut Böhme that the first pictorial representations of ruins date back to the 16th century. She convincingly pointed out that Böhme and I were wrong. Pictures of ruins actually date back to ancient Rome.

11. Translated by the author. German original in Böhme (1989) “Die Ästhetik der Ruinen”. 
It is no surprise then that Albert Speer, Hitler's favourite architect and planner discovered and described the "value of ruins" (Speer, 2005) in what he called a theory. Speer suggested that a good building could become even better once it has fallen apart. It would then remind the successors of the builders of the glory the perished buildings once had. Böhme's suspicion that "German imitations of Italian Renaissance palaces are hardly a memento mori, but a conscious and illusionistic staging of ruins, that is contrasted by the obvious power of the ruling sovereign” (Böhme, 1989: 302) needs to be seen in the light of more recent ruined buildings. Furthermore, Böhme's idea can also help us to understand ruined buildings that are not made of stone and wood, but rather built in $3 \mathrm{D}$ environments, computer simulations and games.

The recent and most technologically advanced construction of artificial ruins happens in the realm of computer games. Film, photography, architecture and literature have, of course, featured ruined buildings, but what we can see now in digital games is far beyond what former media have accomplished. The ruins in games provoke an affective intensity that has been made possible by technological innovation, immersive spatiality and mediatic referentiality.

I suggest exploring four different threads to explain why there are so many ruins in today's computer games. These lines of investigation are informed by

- media history of computer games,

- history of the visual arts,

- psychoanalysis, and

- transmedia megatext. 


\section{History of Decay in Computer Games}

In early computer games, the visuals were restricted by technological limitations such as screen resolution, memory space, and processing power of the consoles. As a consequence, the display of visually complex objects such as animals, humans or spaceships required reduced complexity to a large degree. Spacewar!'s spaceships were displayed as triangles and Pac-Man monsters consisted of 16 by 16 pixels with a colour selected from a 256 bit colour palette. This left little space for textural detail or atmospheric backgrounds, and would make the display of reflections, "imperfections" in geometry, and processes of decay almost impossible. ${ }^{13}$ The resulting aesthetics of coarse pixelation and glossy, naïve squareness was a product of technical constraints rather than a deliberate artistic decision. So, it is quite surprising that, even after the constraints were removed, a look and feel of Lego Worlds persisted, with a few modern games like The Sims (Maxis Entertainment, 2000). These games represent a messy world as a clean virtual environment. Idealized objects are rendered noise-free to the screens. The general trend, however, was an increase in visual and aural artefacts that could be named "digital dust”. It took games history some 30 years to proceed from the simplicity of early '60s games to the games of fog, rust and dust of the 21st century.

13. My colleague Chris Bateman has a point when he states that there were ruins before high-end graphic cards were introduced. I have to admit, that there are "... numerous examples of ruins from the 8-bit era. For a start, Mike Singleton's Tolkien-inspired The Lords of Midnight (Beyond 1984) has ruins dotted around the landscape, and is one of the first videogames to do so. There is also potentially an argument for Gift from the Gods (Denton Designs 1984) qualifying: although the catacombs in this game are lacking in 'digital dust'. I suspect only because of the technical limitations, and there is a definite sense of ruin about them. There's also Paul O'Malley's Arac (Addictive 1986), also known as Spiderbot in some territories, which has a hi-tech zone within an overgrown outer area that suggests something of the new within the ancient, although it is not necessarily a world that fits into your general case here. But most clearly there is Sacred Armour of Antirad (Palace 1986), which is a post-apocalytic game in which the ruins of the older civilisation lie among verdant locations, in the same manner as Arac. Whereas in Arac, some interpretation is needed, Antirad is unequivocally an example that fits your pattern. The longing for ruins goes back right to the dawn of the videogame industry!” (Chris Bateman in an email dated 13 April 2016) The punctuation and italics has been changed by the author. 
By comparing versions of games that had undergone the evolution from a first version to a series of more advanced versions (Unreal Tournament, UT2003, UT2004, Unreal3 or the like) one often finds an increase in special effects and procedural dust that make the games of the more recent past look "older" and more worn out than the earlier versions. This tendency is also visible in avatar skins, haircuts and dresses. Tomb Raider (1996, 1997, etc. until 2012, cont.) is an example of such a transformation. Whereas the early Lara Croft looked like a soft-skinned doll in a clean toy shop, in the latest release she comes with a considerable number of bruises, scars, skin impurities and an unkempt "out of bed" hairstyle. T-shirts of avatars that once looked as if they were nicely ironed, nowadays have to be covered with mud, bloodstains and sweat.

Even ludic nature has become more corroded than it once was. Trees have to have moss on the bark, the feet on the ground have to trace dust tracks, and the air needs to be filled with fog and smoke. The technical reason for this transformation lies in the fact that fog is render-intensive and dust or pollution effects require a higher processing power than a clean and perfect world rendering. Only with advanced video cards did it become possible to generate hyper-realistic fog in the distance, to blur the view when diving in muddy water or to create smoke trails and realistic rain. It may sound paradoxical, but in order to create an imperfect world you need to have a perfect computer. A perfect world is easily generated.

My point here is that it is due to technological advances and progress in the performance of graphics cards that nature could take an active role in games, and that ruins enlivened by natural processes of decay could turn into actors of gameplay. "The landscape is not only something seen and read,” observes Paul Martin. "Landscape [...] is therefore an element of the game that is capable of doing work in relation to the game's story in the same way that we conventionally think of characters doing work. However, while characters work in the representational mode of stories and messages, landscape works primarily through embodiment 
and interaction.” (Martin, 2001: 4) Paul Martin seems to see the ability of landscape to work as a feature that is enabled by a particular design approach, like that of Todd Howard, Ken Rolston and Mark Nelson, game designers of Bethesda Softworks (2006). I would add that designers like those mentioned draw from a portfolio of industry standards and graphic card innovations that allow them to transform landscape in a way that Paul Martin describes so fittingly: "Landscape, in other words, is not a backdrop but the main attraction. The hero is a necessary means of interpreting the landscape.” (Martin, 2001: 4) Along the same lines one might say that advanced games technology enables ruins to become the main attraction. But beyond that the ruin also becomes the main actor. In many contemporary post-apocalyptic games, the hero is just a necessary means of interpreting ruins, the construction of which is now made possible by recent improvements in computer technology. These improvements have expanded the canvas that game designers work on when it comes to conveying narrative and creating gameplay challenges. If we looked at it this way, we could propose that the history of decay in computer games is the journey from imagined decay to perceived decay. In other words: Whilst decay in earlier games was largely based on the imagination of the player, recent games exhibit fully rendered and exaggerated decay, which both shapes narratives and ludic frameworks.

\section{Visualisations of Ruins}

There have been times when the depiction of ruins became common painterly practice. French and Italian Rococo were such periods, German Romanticism definitely was, and the 21st Century seems to have entered a similar phase with computer games like Fallout, S.T.A.L.K.E.R, HalfLife 2 or Metro 2033 - to just name a few. Ruins in Rococo, Romanticism and Pre-Raphaelite painting could stand side by side with recent visualisations of ruins in computer games in regard to the level of sophistication of lighting, perspective, metaphor and allegory. On one hand, there is this level of metaphor and meaning, but there are also formal aspects: the composition of the work of art, perspective, 


\section{ToDiGRA}

position of the viewer, position of the observer relative to the ruin in the image, colours, shadows and light. Caspar David Friedrich's paintings introduced an observer's perspective that looks at the object of the painting across the shoulders of a person in the painting. This mode of looking at an object with the viewer's avatar in the painting has rightly been called a "third-person shooter perspective". 14 The avatars Friedrich introduces, like the "wanderer" in Der Wanderer über dem Nebelmeer (1817) or himself in Auf dem Segler (1818-19) pull the observer into the painting and at the same time create a strange distance to the depicted landscape.

There is also - very similar to computer games - a separation, or enforced discontinuity between foreground and background. In most games, the skybox is a means of separating navigable space from a remote background that cannot be entered by the players of the game. The skybox uses a flat texture (or a series of overlapping textures) surrounding the game world while being completely detached from the navigable geometry, which creates a perfect space of illusion. In Friedrich's paintings it is valleys, mountain ridges or forests that create a perceptual barrier in between perfect nature and the human observing this perfection.

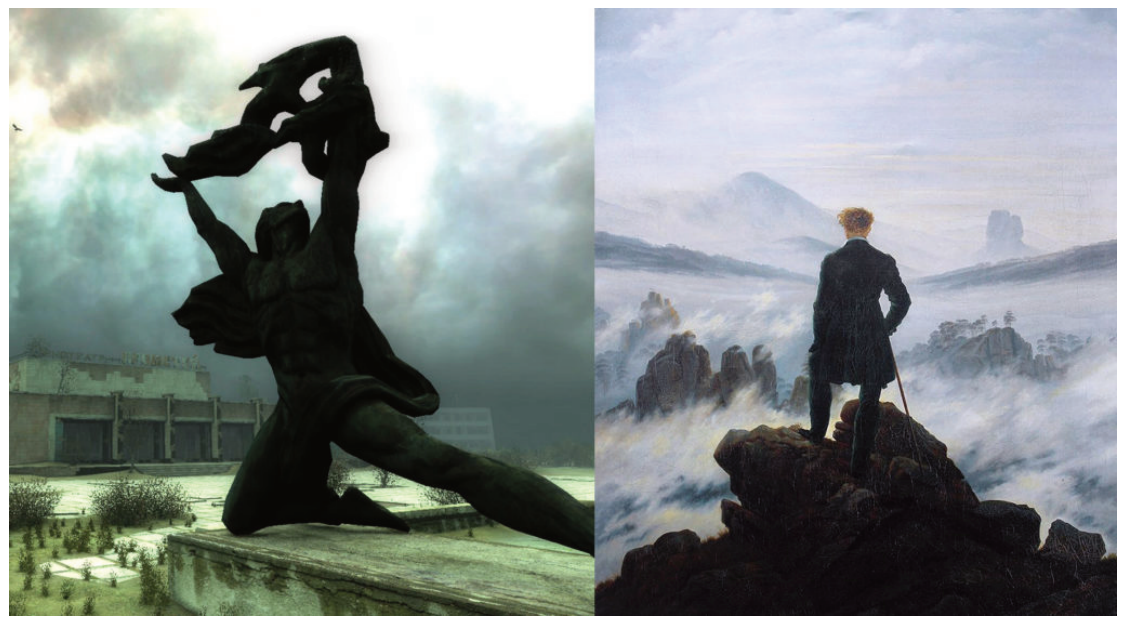

14. cf. David Hancock’s “Romanticism and Computer Games” (PhD dissertation University of Salford, in progress). 
The buildings that turned to ruins are always idealised and not at all realistic depictions of buildings that have broken down. They contain certain elements of ruins like columns and arches, but these elements are arbitrarily repeated and intentionally isolated from the less appealing aspects of decay. In Westfassade der Ruine Eldena mit Backhaus und Scheune (1806) Caspar David Friedrich depicts his favourite ruin, the ruin of Eldena as an idealised structure of gothic arches. These arches reappear in Friedrich's paintings of natural monuments, like the Rügen chalk cliffs, where the cliffs are presented to us in an arch-shaped form. Again, computer games pick up this preference for aesthetically idealised forms of ruins and have us enjoy the arches and the columns and pillars as if we were watching 19th century romantic paintings. Assassin's Creed is a romantic computer game by virtue of its formal arrangement of ruins, and also in regard to the context: Knights and swords were the company of romantic painters would have liked to mingle with, not unlike computer game designers and players of such games. The spatial set-up of players, vis-à-vis ruined buildings, suggests an involvement and an attunement to a situation which Steffen P. Walz describes as "aesthetic and sensual experiences triggered by atmospheres. [... T] his category also includes gazing at landscapes.” (Walz, 2010: 31) The theory of space in architecture and spatial considerations in game design have to be considered as interacting factors “Toward a Ludic Architecture”. (Walz, 2010)

\section{Psychology of the Longing for Decay}

Freud's notion of the death drive seems to be a key concept in understanding why we long for ruins and why we cannot be satisfied with constructive processes or rock-solid perennial objects - in life and in computer games. "There is so much death in games", states Emily Flynn-Jones (2015: 50), and continues: “As a player I am constantly playing with the possibility of death.” Flynn-Jones is trying to "illuminate dark patterns in our gameplay", and refers to Freud's "Beyond the Pleasure Principle" (1920) in the fourth chapter (Flynn- 
Jones, 2015) of the publication "The Dark Side of Game Play." (Mortenson, Linderoth \& Brown eds.) For Sigmund Freud, however, death was not a matter of computer games.

Freud's introduction of the notion of a death drive ("Todestrieb”) in his 1920's publication “Jenseits des Lustprinzips” presents the drive as an anthropological constant that turns us from peaceful and constructive to destructive. The proposition that the death drive opposes eros was disputed by the psychoanalytical community in Freud's day. Wilhelm Reich, amongst others, would have preferred to analyse destructive behaviour as led by a corrupted form of life drive, and not by a proposed death drive that could explain fascination with war, death or ruins. The attempt of Reich to prove that Freud was wrong led to serious confrontation in the International Psychoanalytic Association (IPV) and culminated in Reich's expulsion from the association in 1934. Freud's concept of the death drive was based on a proposed antagonism between organic growth and development on one hand and static regression on the other. "The death drive", said Freud, "strives towards a reestablishment of the anorganic state of livelessness, of stasis and death.” (Freud, 1975: 213) He concluded that neurotic behaviour and repetition compulsion would have to be understood as governed by the death drive. In 1938 Freud published Das Unbehagen in der Kultur in which he insisted on holding the death drive responsible for mass destruction and war. Freud's opponents once more warned against assuming that such a drive would be an integral part of the psyche, yet 20 years later some form of a death drive, then labelled thanatos or death instinct, was once more discussed as a possibility. Melanie Klein as well as Jacques Lacan reinstalled the notion of a death drive. "Those who try to exclude the death drive from their theories misunderstand psychoanalysis," states the philosopher and psychotherapist. (Lacan, 1991: 185) He corrects Freud however in positioning death drives as symbolic. "It is not a question of biology," he says and distinguishes the drive clearly from biologically based instincts that would - according to Freud - aim to direct living, organic structures towards an inanimate state. Slavoj Žižek follows Lacan in proposing that the death drive 
does not refer to literal death, but to death within the symbolic order instead. "We reject language, conceptualization and categorization, but the subject still persists.” (Žižek, 2006: 61) He calls an existence under such conditions "living death" and those who continue living after refuting the symbolic order, "the undead". The repetitiveness of the process of killing elements of the symbolic order was actually something that Freud already pointed out.

Freud observed how repetition is a method of dealing with traumatic experiences, and his description of the "Fort-Da" game his grandson used to play, became crucial for the psychological understanding of the dialectics of destruction and creation. "I eventually realized that it was a game and that the only use he made of any of his toys was to play 'gone' with them. One day I made an observation which confirmed my view. The child had a wooden reel with a piece of string tied around it. It never occurred to him to pull it along the floor behind him, for instance, and play at its being a carriage. What he did was to hold the reel by the string and very skillfully throw it over the edge of his curtained cot, so that it disappeared ...” (Freud, 1975: 225) ${ }^{15}$. We know from the practice of playing computer games that repetition is essential to gaming. Some argue that players identify avatars with real people and that they imitate life, both physically and psychologically, with computer games. Computer games could then be a way of dealing with trauma. It could well be that one of the psychological aspects of playing with ruins is what Sigmund Freud's theory describes as the trauma of repeatedly reliving creation and destruction via play to get relief from this cycle.

\section{Transmedia Megatext}

As in paintings, ruins in computer games often originate from historical buildings or from mediated forms of ruins. Game designers might have been inspired by ruins from movies, paintings, drawings or stories that influenced the design of the in-game ruins. In some cases, there might 
be a direct reference to a non-game object, like a historic ruin. In other cases, the reference aims at a wider concept of ruins and decay. The ruin in the videogame would then pick up a "pathos formula" (Warburg, 2000) or it would refer to a "megatext" (Segal, 1986) and become an "element of the corpus [of a megatext]". (Bateman, 2011: 156) The megatext would, in this case, be constituted by an ensemble of paintings of ruins, stories about ruins, and music in attunement with decay and ruins. Reaching much further than what Charles Segal described in his account of the themes and tales of Greek myths, the "Longing for Decay" megatext crosses the borders of various media and refers to a huge corpus of ruins in film, literature, poetry, music and games. To borrow a phrase that Henry Jenkins used for transmedia objects, also ruins have formerly been "enshrined in stain glass windows or tapestries, told through printed words or sung by bards and poets." (Jenkins, 2003: 3) Today, one might add, the ruins have been ported to computer games as well. This process is somewhat related to what Henry Jenkins calls transmedia storytelling. "Let's face it: we have entered an era of media convergence that makes the flow of content across multiple media channels almost inevitable. The move toward digital effects in film and the improved quality of video game graphics means that it is becoming much more realistic to lower production costs by sharing assets across media." It might however not only be for financial reasons, that game designers "steal" from other media; it seems to be a tradition in storytelling that is older than digital media. "For most of human history, it would be taken for granted that a great story would take many different forms, enshrined in stain glass windows or tapestries, told through printed words or sung by bards and poets, or enacted by traveling performers.” (Jenkins, 2003: 3) No wonder that a story that was strong enough to inspire Andrej Tarkovski in 1978 to build his film Stalker ${ }^{16}$ upon it, crossed media once more for a mediatic reincarnation as the S.T.A.L.K.E.R. computer game. The game's ruins and its tristesse landscape are reminiscent of those in the film (as the latter are reminiscent of the novels') but they are not identical replicas. 
In using transmedia storytelling for the construction of ruins we are offered the possibility to refer to different systems of reference. The ruins in the game S.T.A.L.K.E.R. might remind us of Tarkovski's film, they might also evoke memories and fear of nuclear disaster or they might make us think of game-related features such as sunbeam projection, edge detection algorithms and the like. I do not follow Henry Jenkins' suggestion that an instance of a transmedia storytelling chain can be enjoyed without knowing about the other instances. Different to Jenkins, I think that the full experience of transmedia storytelling lies in the multiplicity of connotations and that any work of art can be best enjoyed by accessing the full range of references. In regard to computer game ruins, I suggest that one will have the best experience of an in-game ruin by contextualizing it to the history of artificial ruins in architecture, to key work from the history of painting, and to the multitude of ruins in literature, film, television, sculpture, politics, etc.

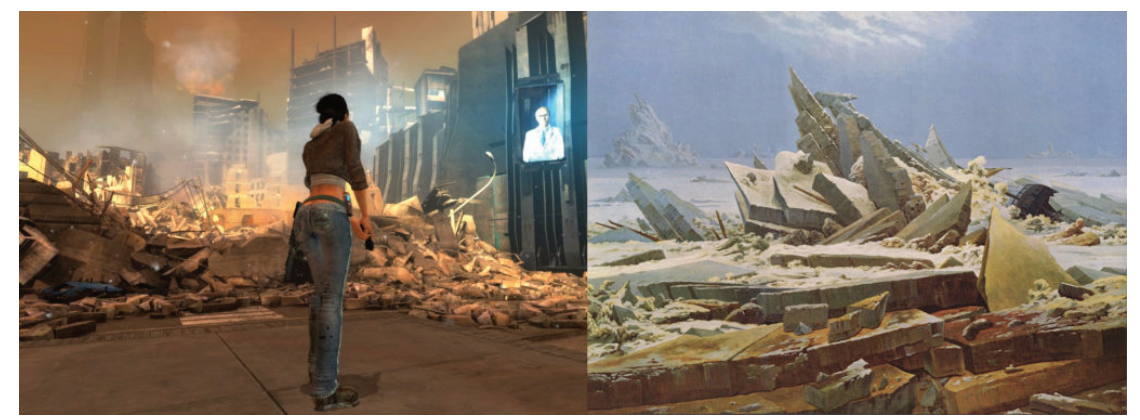

\section{Conclusion}

A ruin is much more than just a certain type of building that has been put together from stones and bricks. Ruins have cultural connotations, architectonic references, hopes and anxiety of a psychological nature, mediatic representations, myths and mysteries. Ruins in computer games carry all of these points of reference in the backpack. They often originate from memories and depictions of historical buildings or from mediated forms of architectonic decay. It is for the very reason of the 
multi-facetted nature of ruins that a multimodal analysis of ruins and decay in computer games has been undertaken in this article.

- In regard to the history of computer games an analysis of technologies available for displaying decay shows that a visually convincing representation of ruins is dependent upon rendering qualities that graphics cards could only achieve from the 1990's onwards.

- The history of German romanticism, as a particular moment in the history of the visual arts, has been analysed in regard to the iconographic similarities of paintings by artists such as Carl David Friedrich and dystopian or nostalgic computer game environments that we encounter in Half-Life 2, S.T.A.L.K.E.R., Fallout, Assassin's Creed etc.

- Psychoanalytic theory offers the concept of the "death drive" to account for a fascination with death, destruction, decay and the beauty of ruins. The death drive is, however, a frequently disputed and controversial model.

- An attempt to name the process of appropriation, creative deconstruction and cross-media transfer of ruins from one medium to another leads to the problem of properly describing this process. The notion of "transmedia storytelling" was introduced by Henry Jenkins (2003; 2008) with the idea of transmedia storytelling being able to open up one fictional world for multiple media within the same franchise. The multireferential nature of ruins in games is often not limited to one single franchise. Jenkins' notion of transmedia storytelling would have to be interpreted broadly to still make sense in this context. "Intertextuality" would be another label that describes the aspect of sharing elements amongst a number of texts when analysing it with the toolset of comparative literature studies. This notion, however, falls short in regard to the element of pathos that is at the core of transmedia ruin representations. Aby Warburg's “pathos formula” (Warburg, 2000) 
might help here, but once more does not capture all aspects of what the author is trying to describe. The working suggestion that has been made here is to call the beast "transmedia megatext" and position the process with one foot in Segal's territory of the "megatext” (Segal, 1986; Bateman, 2011) and with the other foot in Jenkins' "transmedia storytelling". This is obviously a fragile solution that needs to be worked on.

\section{BIBLIOGRAPHY}

Backe, H.-J. \& Aarseth, E. (2013) "Ludic Zombies: An Examination of Zombieism in Games”, in: Proceedings of DiGRA 2013: DeFragging Game Studies.

Bateman, C. (2011) Imaginary Games. Winchester: zero books.

Böhme, H. (1989) “Die Ästhetik der Ruinen”, in: Der Schein des Schönen, eds. Dietmar Kamper \& Christoph Wulf. Göttingen, pp. 287-304.

Dubin, N. L. (2010) Futures \& Ruins: Eighteenth-Century Paris and the Art of Hubert Robert. Los Angeles: Getty Research Institute.

Flynn-Jones, E. (2015) “Don’t Forget to Die: A Software Update is Available for the Death Drive”, in: Mortensen, T., Linderoth, J. and Brown, A. ML. (eds.). The Dark Side of Game Play: Controversial Issues in Playful Environments. New York and London: Routledge.

Fraser, E. (2015) “Awakening in ruins: the virtual spectacle of the end of the city in video games", at: Marx at the Movies, UCLAN, July 1-2, 2015.

Freud, S. (1975) “Jenseits des Lustprinzips”, in: Sigmund Freud Studienausgabe, eds. Alexander Mitscherlich et al., Frankfurt a.M.: Fischer, Vol. 3. 
Ginsberg, R. (2004) The Aesthetics of Ruins. Amsterdam, New York: Rodopi.

Jenkins, H. (2003) Transmedia Storytelling. Moving characters from books to films to video games can make them stronger and more compelling. (MIT Technology review, 15 Jan 2003) http://www.technologyreview.com/news/401760/transmediastorytelling/3/

Jenkins, H. (2008) Convergence Culture: Where Old and New Media Collide. New York: New York University Press.

Krzywinska, T. “Zombies in gamespace: form, context, and meaning in zombie-based videogames”, in: McIntosh, S. and Leverette, M. (eds.). Zombie culture. Autopsies of the living dead. Lanham, Md: Scarecrow Press, 2008, pp. 153-168.

Martin, P. (2001) "The Pastoral and the Sublime in Elder Scrolls IV: Oblivion”, in: Game Studies, International Journal of Computer Games Research, volume 11 issue 3. http://gamestudies.org/1103/articles/martin

Lacan, J. (1991) Subversion des Subjekts und Dialektik des Begehrens im Freudschen Unbewussten (Berlin/ Weinheim: 1991, containing the essay from 1960), pp. 165-204.

Segal, C. (1986) Interpreting Greek tragedy: myth, poetry, text. Ithaca, NY: Cornell University Press.

Speer, A. (2005) Erinnerungen. Berlin: Ullstein Taschenbuchverlag.

Vella, D. (2010) "Virtually in Ruins: The Imagery and Spaces of Ruin in Digital Games”. Masters Dissertation, University of Malta.

Walz, S. P. (2010) Toward a Ludic Architecture. The Space of Play and Games. Pittsburgh: ETC Press. 
Warburg, A. (2000) Der Bilderatlas Mnemosyne, eds. Warnke, M. and Brink, C., Berlin: Akademie Verlag.

Wu Hung (2012) A Story of Ruins. Presence and Absence in Chinese Art and Visual Culture. London: Reaktion Books.

Žižek, S. (2006) Parallaxe. Frankfurt/M.: Suhrkamp.

\section{LudoGRAPHY}

Addictive, Paul O’Malley (1986) Arac

Bethesda Softworks (2008) Fallout 3

Bethesda Softworks, Todd Howard, Ken Rolston \& Mark Nelson (2006) The Elder Scrolls IV: Oblivion

Beyond (1984) Lords of Midnight

Cardboard Computer, Jake Elliott (2011) Ruins

Deep Silver (2013) Metro 2033

Denton Designs (1984) Gods

Eidos Interactive, Toby Gard (1996) Tomb Raider

Epic Games \& Digital Extremes (1999) Unreal Tournament

GSC Game World (2007) S.T.A.L.K.E.R.

Maxis Entertainment (2000) The Sims

Namco (1980) Pac-Man

Palace (1986) Sacred Armour of Antirad

Steve Russell (1962) Spacewar! 
56 ToDiGRA

Ubisoft (2014) Assassin's Creed

Valve Corporation (2004) Half-Life 2 